\title{
PLANTING DENSITY EFFECT ON SOME PROPERTIES OF Schizolobium parahyba WOOD
}

\author{
Luiz Eduardo de Lima Melo ${ }^{1, \star}$, Claudia de Jesus Silva ${ }^{1}$, Thiago de Paula Protásio ${ }^{2}$, \\ Graciene da Silva Mota ${ }^{2}$, Iedo Souza Santos ${ }^{1}$, Claudia Viana Urbinati ${ }^{1}$, \\ Paulo Fernando Trugilho ${ }^{2}$, Fábio Akira Mori ${ }^{2}$
}

In memoriam of Dr. Thomas C. MANNES

\begin{abstract}
This study aims to understand the effect of the initial planting density on the anatomical variability and basic wood density of Schizolobium parahyba var. amazonicum in a planted forest in Amazonia. The effect of the initial planting density on the radial variation from pith to bark of anatomy and basic density was evaluated. There were two planting densities, planting density-I (624 trees ha $\left.{ }^{-1}\right)$ and planting density-II (312 trees ha $\left.\mathrm{a}^{-1}\right)$. Planting density significantly affected only the ray height, fiber length and wall thickness. Radial position was not significant to the height of the rays and the fiber lumen diameter. The interaction planting density $\times$ radial position was only significant for the length of the vessel elements, ray frequency and fiber length. The results indicate that the initial planting density influences the radial behavior of certain anatomical characteristics. To obtain gain in terms of total wood per cultivated area, without harm to the density of the produced wood, planting density-I would be most useful, while planting density-II would be suitable for the production of more homogeneous wood, which tends to form adult wood in advance and with some anatomical characteristics appropriate for the plywood industry.
\end{abstract} density.

Keywords: Amazon, anatomical structure, basic density, paricá wood, radial variation, stocking

\section{INTRODUCTION}

Schizolobium parahyba var. amazonicum, a variation of the species Schizolobium parahyba (Vell.) Blake, of the Fabaceae family, is mainly native to the Amazon, occurring in the states of Northern Brazil (Barneby 1996, Lewis 2015) where it is known as "paricá" and has excelled in homogeneous plantations intended primarily to supply the wood panel industry (Alvino et al. 2005).

Despite the few studies related to forestry and breeding, S. parahyba var. amazonicum has shown satisfactory silvicultural performance in Brazil, as it presents rapid growth and diameter increase. According to ABRAF (2012) the average growth rate of the species in homogeneous stands is 30 to $35 \mathrm{~m}^{3} /$ ha year, higher growth than Pinus spp. (20 to $30 \mathrm{~m}^{3} / \mathrm{ha}$ year) and Tectona grandis (15 to $20 \mathrm{~m}^{3} / \mathrm{ha}$ year) and less than Eucalyptus spp. (up to $50 \mathrm{~m}^{3} / \mathrm{ha}$ year). Considering that in the Amazon the forest exploitation model has led to the impoverishment of biodiversity and the disappearance of certain forest species that suffer high logging pressure, the possibility of establishing plantations of a

\footnotetext{
${ }^{1}$ Universidade do Estado do Pará - Campus VIII, Departamento de Tecnologia e Recursos Naturais, Marabá, PA, Brazil.

${ }^{2}$ Universidade Federal de Lavras, Departamento de Ciências Florestais, Lavras, MG, Brazil.

•Corresponding author: luizeduardo.limamelo@gmail.com

Received: 02.03.2017 Accepted: 05.02.2018.
} 
native species with silvicultural potential, is an alternative to reconcile conservation biodiversity with economic growth and thus achieve sustainable development for the region.

The main purpose of the adoption of silvicultural practices in forest plantations is timber production in satisfactory quantity and quality in order to satisfy the consumer market. The choice of the initial planting density, which reflects the spacing adopted among trees, can influence various wood properties (Weber and Sotelo Montes 2010, Naji et al. 2014), influence the radial variation of the wood anatomical structure, the tree growth rate and consequently have an effect on the quality of the timber produced for the production of panels, in the case of paricá wood.

For the species S. parahyba var. amazonicum Rondon (2002) we noted that the increase in the number of trees per hectare promoted height and diameter reduction of the plants and increased total aerial part biomass production, especially of the tree bark. Melo et al. (2014) observed that increasing the spacing among trees had no significant influence on the basic density and linear and volumetric contractions of the wood of $S$. parahyba var. amazonicum. To our knowledge there is no research information that reports the effect of different silvicultural treatments, especially those regarding different initial planting densities, on the anatomical structure and the radial variation of S. parahyba var. amazonicum wood.

Thus, we believe that the understanding of the interaction between these variables can be useful in deciding the best silvicultural treatment to be adopted for species in the Amazon, so the required amount of wood, with optimal quality, can be produced to satisfy production of the final product.

The aim of this study was to understand the effect of the initial planting density on the anatomical variability and basic wood density of $S$. parahyba var. amazonicum in planted forests in Amazonia.

\section{MATERIAL AND METHODS}

The study was conducted with trees obtained from a commercial paricá (Schizolobium parahyba var. amazonicum (Huber ex Ducke) Barneby) planting, nine years of age, located in the city of Garrafão do Norte in the state of Pará, Brazil ( $01^{\circ} 55^{\prime} 45^{\prime \prime} \mathrm{S}$ and $\left.47^{\circ} 03^{\prime} 24^{\prime \prime} \mathrm{W}\right)$. Soil characteristics were the same for both evaluated planting densities. The soil of the area is the medium texture Yellow Latosol (Oxisol), with the following characteristics within 0-20 cm: $\mathrm{pH}\left(\mathrm{CaCl}_{2}\right)=4,8 ; \mathrm{MO}=20 \mathrm{~g} \mathrm{dm}^{-3} ; \mathrm{P}=3$ $\mathrm{mg} \mathrm{dm}{ }^{-3} ; \mathrm{K}=1,2 \mathrm{mmol}_{\mathrm{c}} \mathrm{dm}^{-3} ; \mathrm{Ca}=21 \mathrm{mmol}_{\mathrm{c}} \mathrm{dm}^{-3} ; \mathrm{Mg}=7 \mathrm{mmol}_{\mathrm{c}} \mathrm{dm}^{-3} ; \mathrm{Al}=5 \mathrm{mmol}_{\mathrm{c}} \mathrm{dm}^{-3} ; \mathrm{H}+\mathrm{Al}=19$ $\mathrm{mmol}_{\mathrm{c}} \mathrm{dm}^{-3}$. The climate is defined as Am2, according to Köppen. The average annual rainfall is 2800 $\mathrm{mm}$ and the average annual temperature, $26^{\circ} \mathrm{C}$. The driest period extends from September to December and the rainiest, from January to May (Viégas et al. 2007).

Five trees were collected in two different initial planting densities (PD), totaling ten trees sampled (Table 1).

Table 1. Basic information on the growth of $S$. parahyba var. amazonicum trees (mean and standard deviation \pm ) evaluated in the two planting densities.

\begin{tabular}{|l|c|c|c|c|}
\hline & No. $\mathrm{t}\left(\right.$ trees ha $\left.^{-1}\right)$ & Pd $(\mathrm{m})$ & Dbh $(\mathrm{cm})$ & $\mathrm{Hb}(\mathrm{m})$ \\
\hline PD I & 624 & $4,0 \times 4,0$ & $23,5 \pm 0,8$ & $15,3 \pm 3,3$ \\
\hline PD II & 312 & $4,0 \times 8,0$ & $25,4 \pm 0,9$ & $12,8 \pm 2,3$ \\
\hline \multicolumn{4}{|c|}{ * PD = planting density; No. $\mathrm{t}=$ number of trees; Pd = planting distance; Dbh = diameter at breast height; } \\
$\mathrm{Hb}=$ Height branch-free stem.
\end{tabular}

A six $\mathrm{cm}$ thick disc was removed from each tree at 1,30 $\mathrm{m}$ from ground level. Four radial positions, pith to bark, were taken from the discs; close to the pith $(0 \%), 33 \%$ and $66 \%$ from the ray, and on the 
periphery of the stem near the bark $100 \%$, from which $2,0 \mathrm{~cm}^{3}$ test bodies were obtained for anatomical analysis and with $3,0 \mathrm{~cm}$ edges in the longitudinal direction $(\mathrm{L}), 2,0 \mathrm{~cm}$ in the radial direction $(\mathrm{R})$ and $2,0 \mathrm{~cm}$ in the tangential direction $(\mathrm{T})$ for density determination (Figure 1).

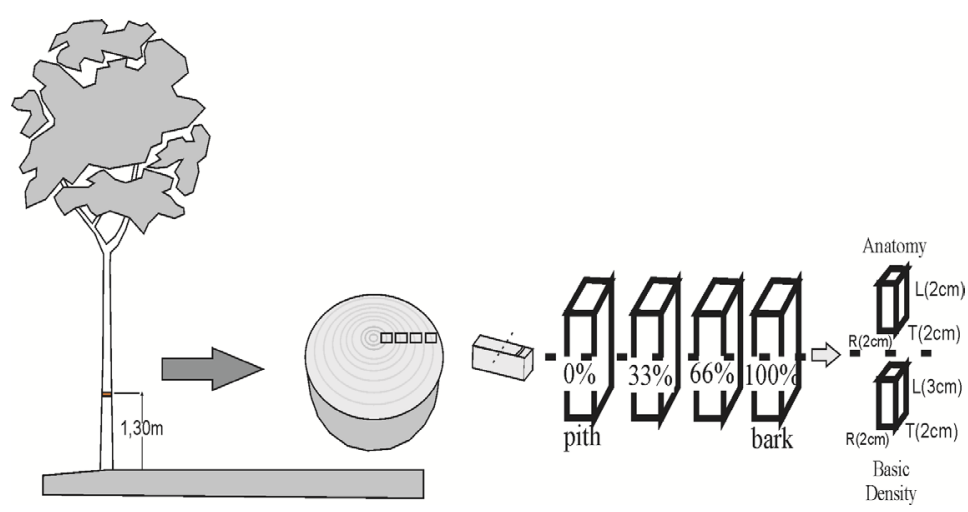

Figure 1. Preparation scheme of test bodies. $\mathrm{R}=$ radial, $\mathrm{T}=$ tangential, $\mathrm{L}=$ longitudinal.

Histological sections were bleached with sodium hypochlorite $(60 \%)$, rinsed thoroughly with water and stained with 1\% safranin (Johansen 1940) and mounted on permanent slides with synthetic resin. For individualization of the anatomical elements we used the maceration method of Franklin (Franklin 1945, modified by Kraus and Arduin 1997). The macerated material was then stained with 1\% aqueous safranin, for the preparation of semi-permanent slides with 50\% glycerol (Strasburger 1924).

The measurements were taken following the recommendations of the IAWA Committee (1989), for the composition of the work, 25 counts and measurements for each anatomical parameter evaluated was fixed. The anatomical characterization was carried out from images obtained with an Olympus BX51 brightfield microscope coupled to an Evolution LC digital camera. Images were analyzed through Image-Pro Plus version 4,5 image analysis software.

The basic density was determined following the test procedure specified by NBR 11941 (ABNT 2003). The size of the test bodies was $2 \times 3 \times 2 \mathrm{~cm}$, defect free and perfectly oriented.

In the evaluation of the wood characteristics, analyses of variance (ANOVA) were carried out considering a completely randomized design (CRD) arranged in a 2 x 4 double factorial, i.e., two planting densities and four radial sampling positions and 5 repetitions. Previously to variance analysis, the homogeneity of variance test (Bartlett test at 5\% significance level) was conducted for all wood characteristics. The analysis of the effect of the radial position of the sampling (quantitative effect) was carried out by adjusting the linear regression models upon verifying statistically a significant effect at $5 \%$ significance by the variance analysis $\mathrm{F}$ test.

\section{RESULTS AND DISCUSSION}

Variance analysis revealed that the initial planting density effect was significant at $5 \%$ significance by the F Test, only for the ray height $(\mu \mathrm{m})$ and wall fiber length and thickness (Table 2). The effect of the radial position was significant for all characteristics evaluated, except for ray height ( $\mu \mathrm{m}$ and No. of cells) and fiber lumen diameter (Table 2). The interaction between initial planting density and radial 
position (PD x RP) was only significant for the length of vessel elements and frequency of ray and fiber lengths (Table 2). Significant interaction indicates that there is dependence among the factors and, thus, for these anatomical features we chose to evaluate the effect of the radial position within each initial planting density to verify their different variation patterns.

Table 2. Summary of the analysis of variance for the S. parahyba var. amazonicum wood characteristics evaluated.

\begin{tabular}{|c|c|c|c|c|c|c|c|c|c|c|c|c|c|}
\hline \multirow{2}{*}{ SV } & \multirow{2}{*}{$\mathrm{DF}$} & \multicolumn{12}{|c|}{ Wood Characteristics. Mean Squares } \\
\hline & & $\mathrm{VF}$ & VD & VEL & $\mathrm{RF}$ & $\mathrm{RH}$ & $\mathrm{RHN}$ & RW & RIWN & $\mathrm{FL}$ & FLD & FIVT & BD \\
\hline PD & 1 & $0,077^{n s}$ & $925,4^{n s}$ & $21,31^{\mathrm{ns}}$ & $0,97^{n s}$ & $13558^{*}$ & $29,4^{\mathrm{ns}}$ & $59,6^{\mathrm{ns}}$ & $0,40 \mathrm{~ns}$ & $108743^{*}$ & $1,25^{\mathrm{ns}}$ & $2,07^{*}$ & $0,001^{13}$ \\
\hline $\mathrm{RP}$ & 3 & $64,5^{*}$ & $34444^{*}$ & $20396^{*}$ & $50,5^{*}$ & $7847^{\mathrm{ns}}$ & $25,1^{\mathrm{ns}}$ & $166,9^{*}$ & $2,24^{*}$ & $607465^{*}$ & $4,41^{\mathrm{ns}}$ & $2,72^{*}$ & $0,055^{*}$ \\
\hline$P D \times R P$ & 3 & $0,35^{\mathrm{ns}}$ & $783,6 \mathrm{~ms}$ & $2903^{*}$ & $1,51^{*}$ & $1975^{\mathrm{ns}}$ & $5,2^{\mathrm{ns}}$ & $40^{\mathrm{mas}}$ & $0,40^{\mathrm{ms}}$ & $23157^{*}$ & $0,81^{\mathrm{ns}}$ & $0,01^{\text {ns }}$ & $0,00^{\mathrm{ns}}$ \\
\hline Error & 32 & 0,42 & 895,9 & 851,5 & 0,45 & 2938 & 10,8 & 39,5 & 0,21 & 4059 & 3,78 & 0,10 & 0,00 \\
\hline $\mathrm{CVe}(\%)$ & - & 16,6 & 12,3 & 7,2 & 8,4 & 16,9 & 16,1 & 20,1 & 15,3 & 5,57 & 10,2 & 12,7 & 8,7 \\
\hline
\end{tabular}

$\mathrm{VF}=$ Vessel frequency $\left(\right.$ No. $\left.\mathrm{mm}^{-2}\right), \mathrm{VD}=$ Vessel diameter $(\mu \mathrm{m}), \mathrm{VEL}=$ Vessel element length $(\mu \mathrm{m}), \mathrm{RF}=$ Ray frequency (No. $\left.\mathrm{mm}^{-1}\right), \mathrm{RH}=$ Ray height $(\mu \mathrm{m}), \mathrm{RHN}=$ Ray height (No.cells), RW = Ray width $(\mu \mathrm{m}), \mathrm{RWN}=$ Ray width (No.cells), FL $=$ Fiber length $(\mu \mathrm{m}), \mathrm{FLD}=$ Fiber Lumen Diameter $(\mu \mathrm{m})$, FWT $=$ Fiber Wall Tickness $(\mu \mathrm{m}), \mathrm{BD}=$ Basic density $\left(\mathrm{g} . \mathrm{cm}^{-3}\right)$. SV $=$ Source of variation; DF = Degrees of Freedom; PD = Planting Density; RP = Radial Position; CVe (\%) = Experimental coefficient of variation; $*=$ significant and n.s $=$ not significant at $5 \%$ of significance by the $\mathrm{F}$ Test.

\section{Effect of initial planting density}

The Table 3 presents the descriptive statistics data and also the multiple comparison of averages conducted for the characteristics evaluated in the initial planting densities. In DP II the broader spacing adopted provided a significant increase of the ray height, $12,2 \%$ and of wall fiber length and thickness 9,5 and $21,7 \%$ respectively.

Table 3. Characteristics of S. parahyba var. amazonicum wood (mean and standard deviation \pm ) in the evaluated planting densities.

\begin{tabular}{|l|c|c|c|}
\hline & PD I & PD II & Mean \\
\hline VF & $3,9 \pm 2,4$ & $4,0 \pm 2,2$ & $3,9 \pm 2,3$ \\
\hline VD & $239,3 \pm 55,0$ & $284,9 \pm 63,6$ & $244,1 \pm 58,9$ \\
\hline VEL & $405,7 \pm 40,8$ & $407,1 \pm 58,7$ & $406,4 \pm 49,9$ \\
\hline RF & $7,8 \pm 2,4$ & $8,1 \pm 1,8$ & $8,0 \pm 2,1$ \\
\hline RH & $303,1 \pm 37,5^{*}$ & $339,9 \pm 71,4^{*}$ & $321,5 \pm 59,3$ \\
\hline RHN & $19,5 \pm 3,0$ & $21,2 \pm 3,7$ & $20,4 \pm 3,5$ \\
\hline RW & $30,1 \pm 6,7$ & $32,5 \pm 7,4$ & $31,3 \pm 7,1$ \\
\hline RWN & $3 \pm 0,66$ & $3 \pm 0,59$ & $3 \pm 0,63$ \\
\hline FL & $1092,1 \pm 200,8^{*}$ & $1196,3 \pm 257,1^{*}$ & $1144,2 \pm 233,7$ \\
\hline FLD & $19,3 \pm 1,6$ & $18,9 \pm 2,1$ & $19,1 \pm 1,9$ \\
\hline FWT & $2,3 \pm 0,5^{*}$ & $2,8 \pm 0,5^{*}$ & $2,5 \pm 0,6$ \\
\hline BD & $0,33 \pm 0,1$ & $0,34 \pm 0,1$ & $0,33 \pm 0,1$ \\
\hline
\end{tabular}

$\mathrm{VF}=$ Vessel frequency $\left(\right.$ No. $\left.\mathrm{mm}^{-2}\right), \mathrm{VD}=$ Vessel diameter $(\mu \mathrm{m}), \mathrm{VEL}=$ Vessel element length $(\mu \mathrm{m}), \mathrm{RF}=$ Ray frequency (No.

$\left.\mathrm{mm}^{-1}\right), \mathrm{RH}=$ Ray height $(\mu \mathrm{m}), \mathrm{RHN}=$ Ray height $($ No. cells $), \mathrm{RW}=$ Ray width $(\mu \mathrm{m}), \mathrm{RWN}=$ Ray width $($ No. cells $), \mathrm{FL}=$

Fiber length $(\mu \mathrm{m}), \mathrm{FLD}=$ Fiber Lumin Diameter $(\mu \mathrm{m}), \mathrm{FWT}=$ Fiber wall thickness $(\mu \mathrm{m}), \mathrm{BD}=$ Basic density $\left(\mathrm{g} . \mathrm{cm}^{-3}\right), \mathrm{PD}=$ planting density. ${ }^{*}=$ statistically different characteristics (F-test $\left.\mathrm{p}<0,05\right)$.

There is no doubt that the density is the main property used as a wood quality index for various end uses. For this study there was no significant effect of initial planting density on the wood density (Table 3), results already reported by other authors (de Lima et al. 2009, Cassidy et al. 2013, Downes 
et al. 2014). However, this is not the standard behavior observed, Roque and Ledezma (2003) for Tectona grandis and Naji et al. (2012), Naji et al. 2014 for Hevea brasiliensis clones, for example, reported increased wood density starting from a reduction in planting density. On the other hand, for Eucalyptus spp., Warren et al. (2009) observed that not all species studied produced higher density wood by reducing the planting density. For Bowyer et al. (2007), in general, the density of hardwood species and diffuse porosity are barely influenced by the spacing among plants, but these results are variable. These discrepancies among results are probably due to differences among the species being evaluated, differences in environmental conditions, and the extent of the planting densities tested.

Some recent research with hardwoods has reported a significant effect of the initial planting density reduction on the anatomical characteristics of the wood produced, such as reduced frequency (de Lima et al. 2011, Naji et al. 2012, Naji et al. 2014) and increased vessel diameter (Naji et al. 2012), besides the tendency towards a ray frequency decrease (Naji et al. 2014) and the increase in fiber length and wall thickness (de Lima et al. 2011, Naji et al. 2012, Naji et al. 2014, Saffian et al. 2014). For our species, significant differences were observed only for the increased height of the rays and of the fiber length and wall thickness, starting from the reduction in initial planting density from 624 to 312 trees ha ${ }^{-1}$ (Table 3). Rondon (2002) noted that when the S. parahyba var. amazonicum species is planted in higher initial spacings there is higher total biomass production of the plant aerial part, as well as in its components, leaves, branches and trunk, and somewhat higher volumetric timber production. According to Naji et al. (2012), these silvicultural characteristics may also lead to increased fiber wall thickness and wood density, however, at higher densities Saffian et al. (2014) explained that the less vital space and higher light competition among individuals, leads trees to grow faster in height, thus cells also develop quicker, having less time for cell wall deposition, leading to production of thinner wall fibers.

Regarding the higher rays observed at lower planting density, we believe that the most favorable conditions for the growth and biomass production, mainly due to the reduced competition for soil nutrients and water, was also responsible for the larger ray dimension in the wood of these trees, since the rays are related to the radial transport and storage of water, sugar and other nutrients (Sauter and Vancleve 1994, O'Brien et al. 2014, Plavcová and Jansen 2015). There are also the biomechanical contributions that have been explored recently, that indicate that the higher proportion of rays in the wood is associated with higher density and radial mechanical stability of the stalk (Burgert and Eckstein 2001, Rahman et al. 2005, Zheng et al. 2013) and these characteristics are expected in the wood produced in less dense plantations.

We can consider that the effect of the initial planting density for the species studied has some implications for the production and use of wood. For example, the fact that we have not found significant differences in the basic density between PD I and PD II is an interesting outcome when evaluating the possibility of gain in terms of total production per area planted by adopting the lower spacing among trees, without, however, there being a significant loss of density of the wood produced.

It should be considered, that in Brazil the wood of the species has mainly been used to supply the plywood panel industry (Alvino et al. 2005), in which the interaction between adhesive and anatomical structure has important influence on the quality of the final product (Albino et al., 2012) and the presence of vessels, fibers and rays has been reported as important parameters in interactions between adhesive and substrate. Albino et al. (2012) found a positive correlation between vessel diameter, length, wall thickness and fiber width, as well as the width of the rays, in number of cells, with shear rupture tension along the glue line. Smith et al. (2002) and Singh and Dawson (2004) reported the positive effect of the rays with the penetration and adhesion of the wood adhesive. Thus the adoption of higher initial planting of the species studied should be considered, since we observed a significant effect, mainly on the ray and fiber dimensions. 


\section{Effect of radial position}

The radial variation of the wood characteristics, in which the effect of PD x RP interaction was not significant, is shown in Figure 2. There was a strong fit for the simple linear model for vessel diameter $\left(r^{2}=0,917\right)$, ray width in micrometres $\left(r^{2}=0,897\right)$ and number of cells $\left(r^{2}=0,898\right)$, fiber wall thickness $\left(r^{2}=0,962\right)$ and the specific gravity $\left(r^{2}=0,991\right)$. However, for the vessel frequency, the quadratic linear model showed better fit $\left(r^{2}=0,973\right)$.
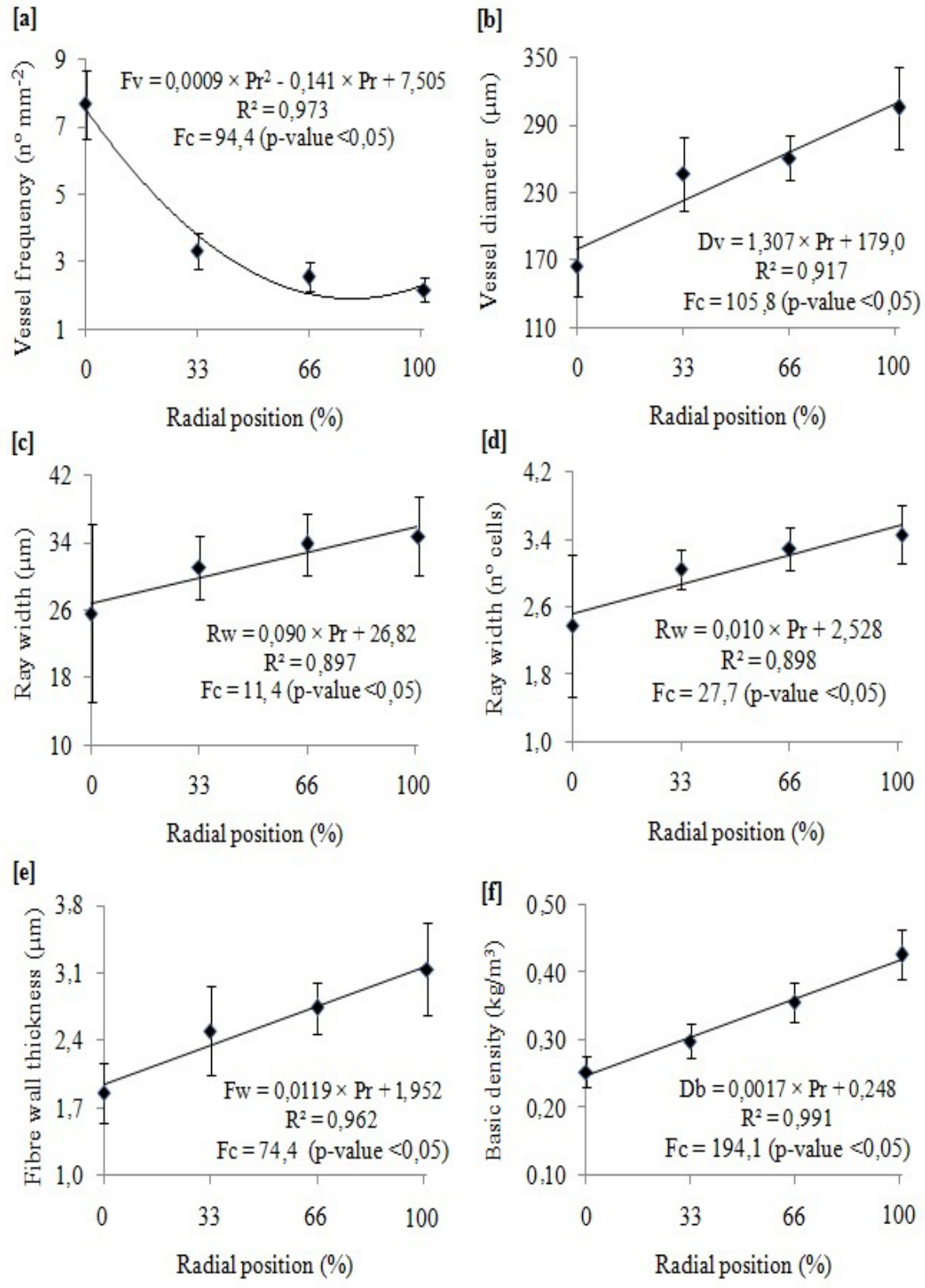

Figure 2. Functional relationship among vessel frequency (a), vessel diameter (b), ray width in micrometers (c), ray width in number of cells (d), fiber wall thickness (e), basic density (f) and radial position in S. parahyba var. amazonicum wood. Error bars with standard deviation. 
The vessel frequency decreases from pith to bark (Figure 3 ). The percentage of reduction of the near-pith position $\left(8 \mathrm{~mm}^{2}\right)$ to the near-bark $\left(2 \mathrm{~mm}^{2}\right)$ was $72 \%$, however, $57 \%$ of this variation is represented by an abrupt decrease in the mean frequency of the vessels near the pith, followed by less marked reduction until near the bark. (Figure 2a). Regarding the vessel diameter, an increased tendency towards variation was observed (Figure 3), the pith increase $(164 \mu \mathrm{m})$ to near the bark $(305 \mu \mathrm{m})$ was $85 \%$, the variation between the two positions, which represented about $50 \%$ of the total variation, was also more significant (Figure 2b).
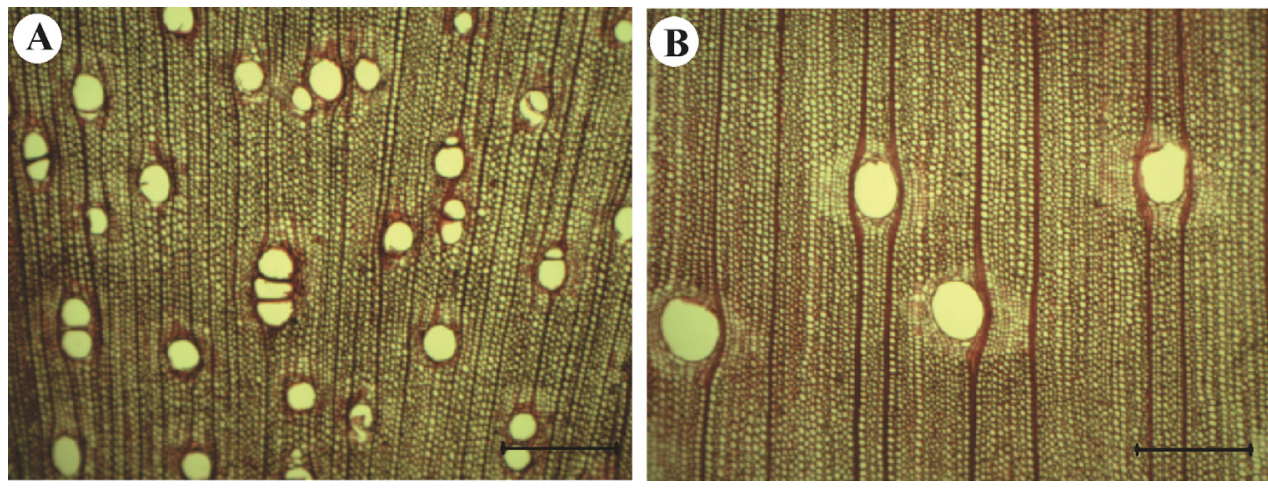

Figure 3. Transverse sections of S. parahyba var. amazonicum wood, showing the vessel frequency and diameter in (a) near the pith and (b) near the bark. Note larger diameter and a lower number of vessels in the wood near the bark. Scale bar $500 \mu \mathrm{m}$.

For the width of the rays $\left(\mu \mathrm{m}\right.$ and No.mm $\left.\mathrm{m}^{-1}\right)$, the minimum value was observed in the first test body near the pith (Figure 4). The width of the rays $(\mu \mathrm{m})$ increased by $35 \%$, ranging from $26 \mu \mathrm{m}$ near the pith to $35 \mu \mathrm{m}$ near the bark. The width of the rays $\left(\mathrm{No}_{\mathrm{mm}}{ }^{-1}\right)$ varied from 2,4 to 3,5 cells, from the pith to the bark, a $45 \%$ variation. For both characteristics, from the second radial position on, there was a decrease in variation magnitude and the values tended to stabilize (Figure 2c, Figure 2d).
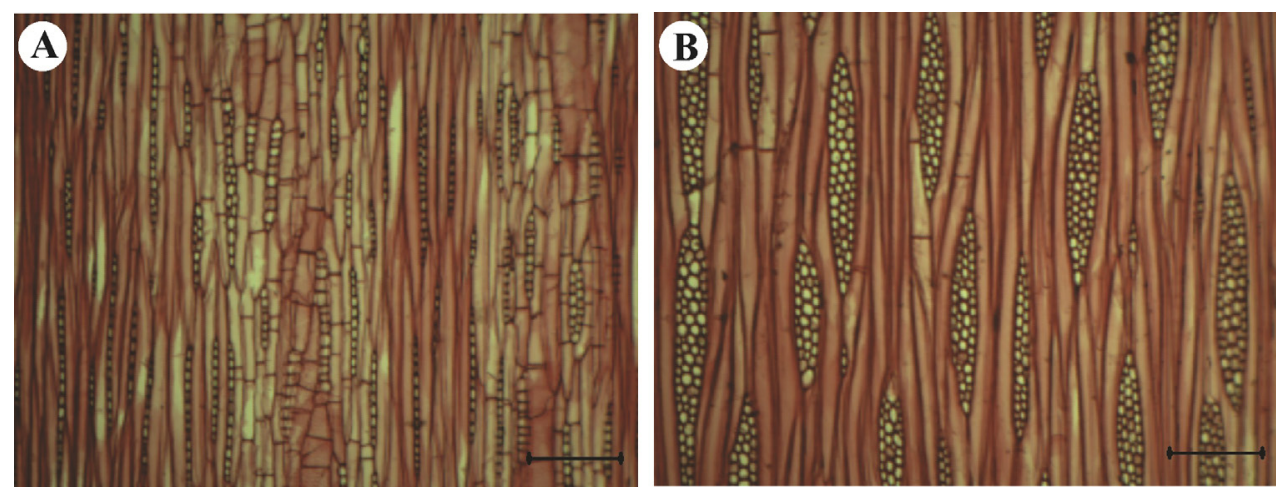

Figure 4. Tangential sections of $S$. parahyba var. amazonicum wood, showing the ray frequency and size in (a) near the pith and (b) near the bark. Note the wider and less frequent rays in the wood near the bark. Scale bar $150 \mu \mathrm{m}$. 
The fiber wall thickness (Figure 2e) and the basic density (Figure 2f) showed very similar behavior, with strong linear and increasing tendency from pith to bark $\left(\mathrm{r}^{2}=0,96\right.$ and $\mathrm{r}^{2}=0,99$ respectively) and a $69 \%$ increase in the fiber wall thickness $(1,9 \mu \mathrm{m}$ to $3,1 \mu \mathrm{m})$ and $68 \%$ in the basic density (250 to $430 \mathrm{~kg} / \mathrm{m}^{3}$ ). For the fiber wall thickness (Figure 2e), the angular coefficients show that for every $1 \%$ increase in the radial position of the pith to bark there is a $0,012 \mu \mathrm{m}$ increase in wall thickness, whereas the basic density (Figure 2f), with the same percentage change, reached an increase of $1,7 \mathrm{~kg} / \mathrm{m}^{3}$, i.e., for every $33 \%$ increase between the radial positions evaluated there is an increase of $0,4 \mu \mathrm{m}$ in the fiber wall thickness and one of $56 \mathrm{~kg} / \mathrm{m}^{3}$ in the basic density.

For the length of the vessel element (Figure 5a), the ray frequency (Figure 5b) and fiber length (Figure 5c) in which there was a significant effect of PD x RP interaction, we assessed the radial variation within each planting density.
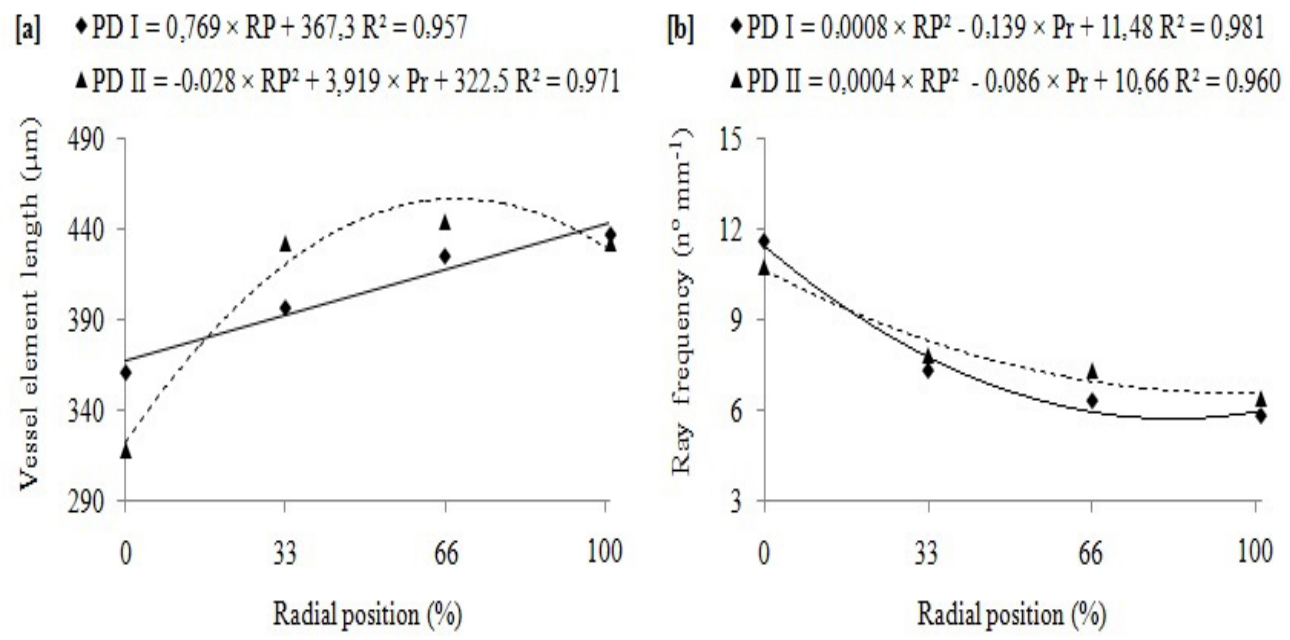

$\begin{aligned} \text { [c] } & \mathrm{PDI}=5,096 \times \mathrm{RP}+838,5 \mathrm{R}^{2}=0,988 \\ \triangle \mathrm{PD} I \mathrm{II} & =-0,086 \times \mathrm{RP}^{2}+14,62 \times \mathrm{Pr}+804,6 \mathrm{R}^{2}=0,996\end{aligned}$

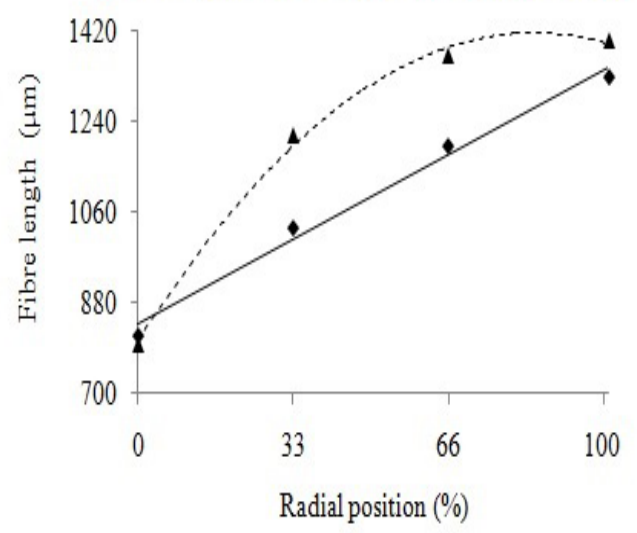

Figure 5. Functional relationship between vessel element length (a), ray frequency (b), fiber length (c), and the radial position in S. parahyba var. amazonicum wood within each evaluated planting density. 
For the length of the vessel element (Figure 5a), the simple linear model $\left(r^{2}=0,957\right)$ showed better fit in PD I, while the quadratic linear model $\left(r^{2}=0,971\right)$ was more effective to explain the radial variation in DP II in which the values increased until the third test body $(445 \mu \mathrm{m})$, when there was a small reduction in the average last radial position near the bark $(432 \mu \mathrm{m})$. For the ray frequency, we observed a downward trend of radial variation with better fit for the quadratic linear model in both planting densities, $\mathrm{r}^{2}=0,981$ and 0,960 for PD I and PD II, respectively (Figure 5b). The ray frequency reduction from pith to bark was 49 and $40 \%$ for DP I and DP II respectively, being most pronounced during the first two positions followed by closer average values nearer the bark, indicating a probable stabilization of values (Figure 5b). The magnitude of radial variation for the ray frequency showed to be higher in the trees with higher planting densities, for DP I the reduction of average values between the two first radial positions was $37 \%$ (12 to 7 No. $\mathrm{mm}^{-1}$ ), a high value compared to DP II in which

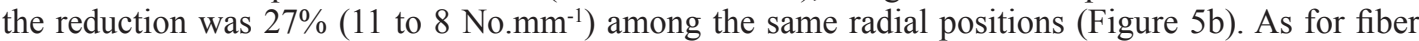
length, as observed for the length of the vessel elements, the simple linear model $\left(\mathrm{r}^{2}=0,988\right)$ fit best to PD I, whereas the quadratic linear model $\left(\mathrm{r}^{2}=0,996\right)$ adjusted best for PD II (Figure $\left.5 \mathrm{c}\right)$. Despite the significant pith to the bark fiber length increase tendency, in both planting densities observed, between the last two radial positions in DP II the fibers ranged from 1370 to $1404 \mu \mathrm{m}$ near the bark, an addition of only $2 \%$ in length, while in PD I the variation between the same radial positions was higher, the fiber length increased from 1191 to $1329 \mu \mathrm{m}$, about a $12 \%$ increase.

For species studied we observed significant radial variation, pith-bark, for most of the evaluated anatomical features, as well as for the basic density. The average value observed for the vessel frequency was higher than that reported by Silva et al. (2016) for the same species as in this present study, however, of native occurrence. For the vessel diameter, similar values were found. The radial association observed between increased vessel diameter and the concomitant reduction in the frequency has been described for hardwoods (Longui et al. 2011, Naji et al. 2013). For this present study we found that this effect was more pronounced in the vicinity of the pith, which may be related to the initial rapid tree-height growth, characteristic of pioneer species, since the vessel elements are strongly influenced by the decreasing auxin concentration gradient along the axial axis of the tree, where the wood produced far from the young leaves, which with the growth in stem diameter comprises the near-pith region, and produced in the opposite direction to the transport of water, tends to present larger and less frequent vessels (Aloni and Zimmermann 1983, Aloni 2013, Sorce et al. 2013). Schuldt et al. (2013) and Zhao (2016) also confirm that during growth, the tree adjusts its anatomical structure, changing, for example, the size and frequency of the vessels to maximize hydraulic conductivity, thereby minimizing the vulnerability of xylem and ensuring mechanical security.

For the length of the vessel elements the overall average observed was similar to that described by Silva et al. (2016) for the same species. There was an tendency towards increasing variation from pith to the bark, as reported in other studies (Dunisch et al. 2004, Tsuchiya and Furukawa 2009), however, at the lowest planting density, there was a small reduction in length near the bark and we believe that this behavior is associated with early maturing cambium in the trees. The length of the vessel elements, as well as the fiber length, is directly related to the cambium fusiform initials, and can be taken as a substitute for fiber when dealing with the demarcation of the area or age of transition between juvenile and mature in hardwood species with diffuse-porous wood. This is because differently from fibers, the vessel elements have little elongation during the differentiation process, having a length similar to that of the fusiform initials from which it originated (Bailey 1920, Kitin et al. 1999, Tsuchiya and Furukawa 2009). Thus we believe that the small reduction of the vessel element length in the lowest planting density may be associated with early maturation of trees, as reported by Naji et al. (2013) for the length of $H$. brasiliensis wood fibers from a lowest planting density.

Studies that have assessed the influence of the diameter growth of trees on the ray dimensions are few. Barghoorn (1941) suggested that in species with multiseriate rays there is a tendency towards increased ray width, pith to bark. Our study supports the Barghoorn suggestion (1941) and we also note that, contrary to this tendency, there was a decrease in the ray frequency towards the periphery of the stem and that for these characteristics, the mean values varied little between radial positions distant from the pith, behavior reported in previous studies (Sun and Suzuki 2001, Rahman et al. 2005, Tsuchiya and Furukawa 2010, Longui et al. 2011).

According to Levyadun and Aloni (1995), the broadening of the rays starting from cambial 
maturation in woody plants is common, since directly or indirectly such broadening is influenced by reduction of auxin from leaves to roots, which promotes a gradual increase in cell size, including ray cells. This behavior may also have important mechanical effects. Rahman et al. (2005) found a positive relationship of width and ray quantity with the density and radial compressive strength in teak wood and Zheng et al. (2013) suggest that larger amounts of radial tissue evolved for greater stem mechanical support. In our study, as presented, the density values were higher near the bark, which leads us to believe that the interaction between these characteristics is related to biomechanical aspects of tree growth.

The average values observed for fiber length and wall thickness, as well as for basic density of the wood analyzed, are in agreement with those reported by other authors (Lobão et al. 2012, Silva et al. 2016) and the standard variation increased from pith to bark. However, for the fiber length, the woods in PD II showed less variation between the last two radial positions. The reduction of the variation magnitude in PDII may be related to early maturation of the cambium and formation of adult wood of the trees, as reported by Naji et al. (2013) for H. brasiliensis. Cobas et al. (2013), on determining the age of transition between juvenile and adult wood of Populus deltoides planted in Argentina, reported based on a study of fiber length, the early transition age of juvenile wood to adult around a tree age of 9 years. The presence of lower density wood and with smaller fibers near the pith, followed by a sharp increase of these properties towards the periphery of the stem, is a common pattern reported in the literature, and represents the effect of cambium age on wood characteristics (Zobel and Van Buijtenen 1989, Ishiguri et al. 2009, Longui et al. 2011, Omonte and Valenzuela 2011, Naji et al. 2012) and also has considerable effect on the quality of the wood produced.

\section{CONCLUSIONS}

This study demonstrated that the height of the rays and wall fiber length and thickness exhibit significant variation in function of the initial planting density adopted. According to the radial position from which the wood is obtained, with the exception of ray height and fiber lumen diameter, all other characteristics are significantly affected.

We further verified that the initial planting density has considerable influence on the magnitude and radial behavior of the ray frequency, the length of the vessel elements and fibers. We suggest that these results may be related to the possibility of premature formation of adult wood in the trees of the lowest planting density.

Thus, we believe that, depending on the initial planting density adopted, it can influence the formation of wood in S. parahyba var. amazonicum planted in the Amazon. If the goal of planting is to succeed in terms of total wood production per area planted, with the only concern being that there is no density loss in the wood produced, the higher initial planting density (PD I) should be adopted, whereas the lower initial planting density (PD II) would be suitable for the more homogeneous timber production, which tends to form adult wood in advance and which presents certain anatomical features that can improve the quality of wood for the plywood industry.

\section{ACKNOWLEDGEMENTS}

The authors are grateful to CNPq and CAPES for the financial support and scholarship for carrying out this work. Our special thanks go to researchers Dr. Pedro Lisboa of the Museu Paraense Emilio Goeldi and Dr. Joaquim I. Gomes of the Embrapa Amazônia Oriental for being one of the forerunners in wood anatomy studies in the Amazon. The authors especially gratefully acknowledge of Mr. Benedito 
C. dos Santos and Mrs. Maria F. Souza Santos for providing accommodation and allow access to the area of collection of trees. Finally the authors thank the reviewers for their valuable comments and suggestions to improve the quality of the paper.

\section{REFERENCES}

Albino, V.C.S.; Mori, F.A.; Mendes, L.M. 2012. Influência das características anatômicas e do teor de extrativos totais da madeira de Eucalyptus grandis W. Hill ex Maiden na qualidade da colagem. Ciência Florestal 22: 803-811.

Aloni, R. 2013. Role of hormones in controlling vascular differentiation and the mechanism of lateral root initiation. Planta 238: 819-830.

Aloni, R.; Zimmermann, M.H. 1983. The control of vessel size and density along the plant axis - a new hypothesis. Differentiation 24: 203-208.

Alvino, F.O.; Silva, M.F.F.; Rayol, B.P. 2005. Potencial de uso das espécies arbóreas de uma floresta secundária, na Zona Bragantina, Pará, Brasil. Acta Amazonica 35: 413-420.

ABNT. ASSOCIAÇÃO BRASILEIRA DE NORMAS TÉCNICAS. 2003. Madeiradeterminação da densidade básica. NBR 11941: Rio de Janeiro, 6 p.

ABRAF. ASSOCIAÇÃO BRASILEIRA DE PRODUTOS FLORESTAIS. 2012. Anuário ABRAF 2012 ano base 2011. Brasília. 145 p.

Bailey, I.W. 1920. The cambium and its derivative tissues II. Size variations of cambial initials in gymnosperms and angiosperms. American Journal of Botany 7: 355-367.

Barghoorn, E.S. 1941. The ontogenetic development and phylogenetic specialization of rays in the xylem of dicotyledons. II. Modification of the multiseriate and uniseriate rays. American Journal of Botany 28: 273-282.

Barneby, R.C. 1996. Neotropical Fabales at NY: Asides and Oversights. Brittonia 48: 174-187.

Bowyer, J.L.; Shmulsky, R.; Haygreen, J.G. 2007. Forest products and wood science: an introduction. 5th edn. Blackwell, Iowa, p 558

Burgert, I.; Eckstein, D. 2001. The tensile strength of isolated wood rays of beech (Fagus sylvatica L.) and its significance for the biomechanics of living trees. Trees 15: 168-170.

Cassidy, M.; Palmer, G.; Smith, R.G.B. 2013. The effect of wide initial spacing on wood properties in plantation grown Eucalyptus pilularis. New Forests 44: 919-936.

Cobas, A. C.; Area, M. C.; Monteoliva, S. 2013. Transición de madera juvenil a madura en un clon de Populus deltoides implantado en Buenos Aires Argentina. Maderas-Cienc Tecnol 15(2): 223234.

Franklin, G.L. 1945. Preparation of thin sections of synthetic resins and wood-resin composites, and a new macerating method for wood. Nature 155: 51.

Downes, G.; Harwood, C.; Washusen, R.; Ebdon, N.; Evans, R.; White, D.; Dumbrell, I. 2014. Wood properties of Eucalyptus globulus at three sites in Western Australia: effects of fertiliser and plantation stocking. Australian Forestry 77: 179-188.

Dunisch, O.; Reissmann, C.B.; Oliszeski, A. 2004. Variability of vessel characteristics in the 
xylem of Ilex paraguariensis (mate-tree) from South Brazil. IAWA Journal 25: 449-458.

IAWA Committee. 1989. IAWA list of microscopic features for hardwood identification. IAWA Bull. n.s. 10: 219-332.

Ishiguri, F.; Hiraiwa, T.; Iizuka, K.; Yokota, S.; Priadi, D.; Sumiasri, N.; Yoshizawa, N. 2009. Radial variation of anatomical characteristics in Paraserianthes falcataria planted in Indonesia. IAWA Journal 30: 343-352.

Johansen, D.A. 1940. Plant microtechnique. McGraw-Hill Book Co., Inc: New York.

Kitin, P.; Funada, R.; Sano, Y.; Beeckman, H.; Ohtani, J. 1999. Variations in the lengths of fusiform cambial cells and vessel elements in Kalopanax pictus. Annals of Botany 84: 621-632.

Kraus, J.E.; Arduin, M. 1997. Manual básico de métodos em morfologia vegetal. Rio de Janeiro, EDUR. 25 pp.

Levyadun, S.; Aloni, R. 1995. Differentiation of the ray system in woody-plants. The Botanical Review 61: 45-84.

Lewis, G.P. 2015. Schizolobium in Lista de Espécies da Flora do Brasil. [online] Jardim Botânico do Rio de Janeiro. Available: <http://floradobrasil.jbrj.gov.br/jabot/floradobrasil/FB23144>.

Lobão, M.S.; Costa, D.P.; Almonacid, M.A.A.; Tomazello Filho, M. 2012. Qualidade do lenho de árvores de Schizolobium parahyba var. amazonicum Acre, Brasil. Floresta e Ambiente 19: 374-384.

Longui, E.L.; de Lima, I.L.; Andrade, I.M.; Freitas, M.L.M.; Florsheim, S.M.B.; Zanatto, A.C.S.; da Silva, F.G. 2011. Seed provenance influences the wood structure of Gallesia integrifolia. IAWA Journal 32: 361-374.

Lima de, I.L.; Florsheim, S.M.B.; Longui, E.L. 2009. Influência do espaçamento em algumas propriedades físicas madeira de Tectona grandis Linn. Cerne 15: 244-250.

Lima de, I.L.; Garcia, R.; Longui, E.L.; Florsheim, S.M.B. 2011. Dimensões anatômicas da madeira de Tectona grandis Linn. Em função do espaçamento e da posição radial do tronco. Scientia Forestalis 39: 61-68.

Melo, L.E.L.; Silva, C.J.; Protásio, T.P.; Trugilho, P.F.; Santos, I.S.; Urbinati, C.V. 2014. Influence of spacing on some physical properties of Schizolobium parahyba var. amazonicum (Huber ex Ducke). Scientia Forestalis 42: 483-490.

Naji, H.R.; Bakar, E.S.; Soltani, M.; Ebadi, S.E.; Abdul-Hamid, H.; Javad, S.K.S.; Sahri, M.H. 2014. Effect of Initial Planting Density and Tree Features on Growth, Wood Density, and Anatomical Properties from a Hevea brasiliensis Trial Plantation. Forest Products Journal 64: 41-47.

Naji, H.R.; Sahri, M.H.; Nobuchi, T.; Bakar, E.S. 2012. Clonal and planting density effects on some properties of rubber wood (Hevea brasiliensis muell. Arg.). Bioresources 7: 189-202.

Naji, H.R.; Sahri, M.H.; Nobuchi, T.; Bakar, E.S. 2013. Radial variation of wood cell features under different stocking densities management of two new clones of rubberwood (Hevea brasiliensis). Journal of Wood Science 59: 460-468.

O’Brien, M.J.; Leuzinger, S.; Philipson, C.D.; Tay, J.; Hector, A. 2014. Drought survival of tropical tree seedlings enhanced by non-structural carbohydrate levels. Nature Climate Change 4: 710714.

Omonte, V.; Valenzuela, L. 2011. Variación radial y longitudinal de la densidad básica en árboles de Eucalyptus regnans de 16 años. Maderas-Cienc Tecnol 13(2):211-224.

Plavcová, L.; Jansen., S. 2015. The role of xylem parenchyma in the storage and utilization of non-structural carbohydrates. In: Hacke UG (Ed.), Functional and ecological xylem anatomy: 209-234. Springer, Switzerland. 
Rahman, M.M.; Fujiwara, S.; Kanagawa, Y. 2005. Variations in volume and dimensions of rays and their effect on wood properties of teak. Wood and Fiber Science 37: 497-504.

Rondon, E.V. 2002. Produção de biomassa e crescimento de árvores de Schizolobium amazonicum (Huber) Ducke sob diferentes espaçamentos na região de mata. Revista Arvore 26: 573-576.

Roque, R.M.; Ledezma, V.A. 2003. Efecto del espaciamiento em plantación sobre las propiedades físicas de madera de teca a lo largo del fuste. Madera y Bosques 9: 15-27.

Saffian, H.A.; Tahir, P.M.; Harun, J.; Jawaid, M.; Hakeem, K.R. 2014. Influence of Planting Density on the Fiber Morphology and Chemical Composition of a New Latex-timber Clone Tree of Rubberwood (Hevea brasiliensis Muell. Arg.). Bioresources 9: 2593-2608.

Sauter, J.J.; Vancleve, B. 1994. Storage, mobilization and interrelations of starch, sugars, protein and fat in the ray storage tissue of poplar trees. Trees 8: 297-304.

Schuldt, B.; Leuschner, C.; Brock, N.; Horna, V. 2013. Changes in wood density, wood anatomy and hydraulic properties of the xylem along the root-to-shoot flow path in tropical rainforest trees. Tree Physiology 33: 161-174.

Silva, M.G; Mori, F.A.; Ferreira, G.C.; Ribeiro, A.O.; Carvalho, A.G.; Barbosa, A.C.M.C. 2016. Estudo anatômico e físico da madeira de Schizolobium parahyba var. amazonicum proveniente de povoamentos nativos da Amazônia Oriental. Scientia Forestalis 44: 15-27.

Singh, A.P.; Dawson, B.S.W. 2004. Confocal microscope - A valuable tool for examining woodcoating interface. Journal of Coatings Technology and Research 1: 235-237.

Smith, M.J.; Dai, H.M.; Ramani, K. 2002. Wood-thermoplastic adhesive interface - method of characterization and results. International Journal of Adhesion and Adhesives 22: 197-204.

Sorce, C.; Giovannelli, A.; Sebastiani, L.; Anfodillo, T. 2013. Hormonal signals involved in the regulation of cambial activity, xylogenesis and vessel patterning in trees. Plant Cell Reports 32: 885898.

Strasburger, E. 1924. Handbook of practical botany for the botanical laboratory and private student. 8th ed. London, George Allen and Unwin, Ltd.

Sun, Q.; Suzuki, M. 2001. Quantitative character variations of cambial derivatives in mangroves and their functional significance. Trees 15: 249-261.

Tsuchiya, R.; Furukawa, I. 2009. Radial variation in the size of axial elements in relation to stem increment in Quercus serrata. IAWA Journal 30: 15-26.

Tsuchiya, R.; Furukawa, I. 2010. Relationship between the radial variation of ray characteristics and the stages of radial stem increment in Zelkova serrata. Journal of Wood Science 56: 495-501.

Viégas, I.J.M.; Ramos, E.J.A.; Thomaz, M.A.A.; Sato, T. 2007. Efeito da adubação de NPK em plantas jovens de paricá. Embrapa Pará - Belém 8 p. (Embrapa Pará - Belém. Comunicado Técnico, 193).

Warren, E.; Smith, R.G.B.; Apiolaza, L.A.; Walker, J.C.F. 2009. Effect of stocking on juvenile wood stiffness for three Eucalyptus species. New Forest. 37: 241-250.

Weber; J.C., Sotelo Montes, C. 2010. Correlations and clines in tree growth and wood density of Balanites aegyptiaca (L.) Delile provenances in Niger. New Forests 39: 39-49.

Zhao, X.P. 2016. Spatial variation of vessel grouping in the xylem of Betula platyphylla Roth. Journal of Plant Research 129: 29-37.

Zheng, J.M.; Martinez-Cabrera, H.I. 2013. Wood anatomical correlates with theoretical conductivity and wood density across China: evolutionary evidence of the functional differentiation of axial and radial parenchyma. Annals of Botany 112: 927-935. 
Zobel, B.J.; Van Buijtenen, J.P. 1989. Wood Variation: Its Causes and Control. Springer-Verlag, Berlin. 363 pp. 